ESJ Social Sciences

\title{
Performance Supervision and Employees' Productivity in the Ministry of Lands, Environment and Natural Resources of Taita Taveta County, Kenya
}

Dorothy Ndembo Mwasawa, MBA

Dr. Lawrence Wainaina, PhD

School of Business, Kenyatta University, Kenya

Doi:10.19044/esj.2021.v17n19p128

Submitted: 03 May 2021

Accepted: 24 June 2021

Published: 30 June 2021
Copyright 2021 Author(s)

Under Creative Commons BY-NC-ND

4.0 OPEN ACCESS

Cite As:

Ndembo Mwasawa D. \& Wainaina L. (2021). Performance Supervision and Employees' Productivity in the Ministry of Lands, Environment and Natural Resources of Taita Taveta County, Kenya.

European Scientific Journal, ESJ, 17(19), 128. https://doi.org/10.19044/esj.2021.v17n19p128

\section{Abstract}

The objective of the study was to find out the effect of performance supervision on employees' productivity in the Ministry of Lands, Environment, and Natural Resources in Taita Taveta County. Goal-setting theory and equity theory form theoretical frameworks. A descriptive research design was adopted in this study. The target population was 262 employees. Stratified random sampling was implemented to produce a sample for the study. To ascertain its level of reliability, the research instrument was pilot tested before the actual data collection. Respondents were requested to correct the contents of the questionnaire and experts were consulted to enhance the instrument's validity. Questionnaires were issued to respondents and recollected thereafter for analysis. Sorting was conducted on the collected data. Descriptive statistics and inferential statistics were employed to analyze quantitative data. The study established that performance supervision had a positive connection with employee productivity. Therefore, the study recommended that institutions need to strive towards achieving effective supervision since it provides a safe environment for employees to reflect on their practice, as well as to develop skills and knowledge. The delivery of effective supervision is heavily dependent on the organizational context due to the dynamics surrounding the role of supervision. For the Ministry to realize high output, the outcome points in the direction of good supervision, which is 
believed to contribute to increased job satisfaction, increased job and organizational commitment among staff, and reduced employee turnover.

Keywords: Performance supervision, monitoring, objectives, Employee productivity

\section{Introduction}

\section{Background of the study}

There have been ample studies done globally and in Africa on the association between supervision and employee productivity, (Koske \& Atambo, 2018,). The abilities associated with the supervisor's character have a significant influence on an employee's performance as well as his behavior, which includes professional and moral support as well as creating a comprehensive workplace that aids in the improvement of subordinates' performance (Min, Iqbal, Khan, Akhtar, Anwar, \& Qalati,2020).An investigation into what makes public institutions productive and efficient is a subject that has given academicians and human resource management consultants sleepless nights for decades, (Paula, Sanna, Juhani \& Helina, 2014). Furthermore, low employee productivity reported in state-owned institutions is not only instigated by a lack of work experience and expertise, but also comes from management, work inspiration, and capabilities, (Syamsuddin, Kadir, \& Alam, 2020). Production of quality goods and services by applying the idea of all-purpose administration alignment to public services, is the demand by broader community. This has catalysed changes in present-day state owned organizations. (Hamid, Haming, Semmaila \& Bijang,2020)

Supervision is an activity that involves getting the job done with an established plan and a desired result (Lubis, 2015). The supervisor needs to ensure that duties and responsibilities are assigned to an employee who has attained minimum qualifications and the roles are clearly understood. Performance supervision is intended to improve learning from experience and learning through doing, guided by the policies and procedures governing the institution. Improvement in efficiency to achieve competitive advantage is among the many ways in which organizations make use of their employees, (Ataullah \& Sahota, 2014). In the management of employees' performance by increasing and sustaining high output continuously, flexibility has proven to be a vital intervention tool for leaders and human resources. This not only supports the development of good work but aims to concretize supervision management in an organised harmonious work environment, (Kelly, Rofcanin, Heras, Ogbonnaya Marescaux \& Bosch,2020).

Employee productivity is an evaluation of an employee or employee's effectiveness and it is the actual element that has a direct effect on the 
company's profits, (Hanaysha,2016). Productivity is the state of accomplishing organizational intentions and objectives by converting inputs into outputs efficiently for humanity's advantage. The success and image of any institution depend on the workers, who are the most treasured factor in its production. They have an impact on the company's quality of service delivery, which contributes to customer satisfaction. Therefore, for organizations to attain competitive advantage, HRM plays a vital part in managing labor (Riaz, 2017).

\section{Literature Review \\ Theoretical Framework \\ Goal setting Theory}

Assurance of the goals, plus, given sufficient capability, the higher the goal, the higher the performance. This is because individuals typically modify their level of effort to the difficulty of the goal, (Latham \& Locke,2017). Attainment of set goals and targets has a positive effect on one's self esteem and contributes to self-confidence and productivity, (Ime, Victor, Osemudiamen \& Efiok, 2015).

Excellence in performance depends on precision in setting goals and targets which are realistic and measurable. Human resources are a firm's vital possessions alongside application of supervision as well as operative functions to realize company goals set through appropriate human resource management (Sinambela 2016). The significance of goals as a morale booster for any institution offers the workforce precision and quantifiable targets that can be realized with ease, (Kopaneva \& Sias, 2015). The perception of goal setting theory is that employees who have goals which are SMART attain superior performance as compared to those who develop ambiguous goals or none, (Kihama \& Wainaina, 2019). The importance of performance management in formulating and implementing SMART goals which can be managed with ease is reinforced by goal setting theory.

\section{Equity theory}

John A. Stacy, (1963), propounded the equity theory, which is related to the perceptions people have about how they are being preserved in relation to relevant others. Equity is the way an employee evaluates the state of affairs based on inputs and outcomes, (Bell \& Martin 2012,). Equity is achieved when one is fairly treated equitably in comparison with another relevant person. The dominance of equity in an institution creates an environment of security which employees need to be productive. Employee demoralization is exacerbated by a lack of equity, which discourages employees from performing to expectations. This leads to an organization reporting low productivity (Benowitz, 2017). Tension and distress occurs when employees observe or 
feel unevenness in the proportion of their input-outcome in relation to relevant others. Organizations at large should put more effort into eliminating inequalities and unevenness as this assures employees a secure environment for optimum performance, which leads to superior and improved efficiency, (Inuwa, 2017).

For supervisors to develop clear job accountabilities and expectations, operational performance management structures must be put in place to facilitate a worker's development in line with his/her behavior, aiming towards the institution's planned goals and objectives (Okeke et al 2019). Supervisors need to create an environment which equally enables employees to perform excellently by clearly passing on information concerning what the job requires and instituting reasonable as well as reliable performance goals for the entire workforce, (Tara,2016). When the relevant authority manages and treats employees with equity, there will be no tension amongst employees. Hence, they will all work towards attaining the goals of the ministry.

\section{Empirical Review}

In the study done by (Hannang, Salju \& Qamaruddin,2020), they adopted a quantitative descriptive approach with the objective of determining the effect of Supervision Levels on Employees' Performance Levels in the City of Manpower Office of Palopo. The researchers suggested that leaders carry out repetitive assessments of subordinate workstations, carryout consultations, and evaluations to determine obstacles to employee performance. Further, the study concluded that the level of supervision has a positive influence on employee performance at the Palopo City Manpower Office.

Lee \& Kusumah, (2020) examined the effect of supervision on employee performance with work motivation as an intervening variable. It was an empirical analysis that used a quantitative approach to verify the influence of the variables under study. The outcomes of the data analysis showed that supervision has a positive influence on employee performance through work motivation as an intervening variable. This research recommended businesses to embrace methods and formulate strategies that stimulate enthusiasm, create effective and resourceful supervisory practices to enhance employee performance, as well as advance business performance according to previously agreed business goals.

Asrizal and Lesmana, (2018), investigated the influence of work discipline and supervision on increasing employee productivity in Citra Robin Sarana Medan. It was causal associative research using a quantitative approach. The results positively showed that, simultaneously, work discipline and supervision had a momentous influence on workers' productivity. Supervisory functions undertaken by supervisors and managers should be 
more effective in accordance with the standards set by the company, was the conclusion made by the research.

Supervision of the performance of an organization is largely determined by the employees who work in it. Employees are the driving force behind an organization's operations; thus, as employee performance improves, so does organizational performance (Syamsuddin et al 2020). Supervisors are responsible for the work environment of employees related to work (Hamida et al 2020). The involvement of supervision in work also enriches employees' experience in terms of quality. Rulandari (2017) confirmed that some of the managerial recommendations for improving workforce performance included matching work results with standard controls, improving the execution of regular supervision, and performing critical counteractive actions. Additionally, increasing the level of understanding of the job assigned, work assertiveness and work plans for the staff. It was evidently proven that there was an affirmative influence of supervision and professionalism on workers' performance in the office under investigation.

\section{Research Methodology \\ Research Design}

A research design is an all-purpose plan for how the investigator will go about collecting data and analysing it, guided by the objectives of the study. A descriptive research design was adopted for the study. This design involves measuring phenomena in their natural environment. It allows the amalgamation of quantitative and qualitative techniques. The design is useful as it offers a truthful and exact explanation of actions in the study area (Babbie, 2013).

\section{Target Population}

The study was conducted in the Lands, Environment and Natural resources sector of Taita Taveta County. The target population was heterogeneous and incorporated different directorates. The total population of employees in this sector was 262 .

\section{Sampling Technique}

The sample size of the study is a minor portion of the target population. There was a need to cautiously select a sample that was representative of the whole population. It involved dividing the population into strata (groups). These strata had equal probabilities of an employee being selected in addition to each stratum of the sample. In this case, the stratum consisted of 5 directorates in the ministry. 


\section{Sample Size}

Sample size refers to a predetermined number of people carefully chosen from the targeted population in order to establish a sample for the purposes of data collection. The sample size was collected as a result of efficiency, effectiveness and reliability. The formula adopted for the study was Naissuma, (2008).

Where: $\quad n=$ required sample size

$$
n=\frac{\mathrm{N} C^{2}}{C^{2}+(\mathrm{N}-1) e^{2}}
$$

$\mathrm{N}=$ population

$C=$ a constant of discrepancy in the range of $21 \% \leq C \leq 30 \%$

$e=$ standard error in the range of $2 \% \leq e \leq 5 \%$

Therefore, at $C=28 \%$ and $\left.e=3 \%: \mathrm{n}=\frac{262(0.28)^{2}}{0.28^{2}+(262}-1\right) 0.03^{2}$

$$
n=\frac{262 \times 0.0784}{0.0784+261(0.0009)}
$$

$n=20.5408=65.56$

$$
n=66^{0.3133}
$$

\section{Data Collection Instrument}

A questionnaire with a Likert scale was used to generate primary data. A Likert scale was incorporated into the questionnaire and it contained a series of statements, inviting the respondent to respond to each question based on one's own perspective on a sliding scale of 1-4 (1=strongly agree, 2 agree, 3 disagree and 4 strongly disagree). Questionnaires are instruments for collecting primary data. They can be issued with ease to a huge population without the presence of researchers.

\section{Reliability}

The use of a questionnaire was more reliable in the study. Once the questionnaire had been filled in by the respondent, it was handed over to the researcher within one week. The reliability of a research instrument is judged after that instrument produces consistent results after being administered to different samples drawn from the target population, (Warrens, 2015).

\section{Validity}

In qualitative research, validity refers to the suitability of the procedures, processes, instruments, and data used in the study (Leung, 2015). Content validity establishes whether the items in the data collection instrument 
are in agreement with the objectives of the research. To ensure only what is planned for is measured by the questionnaire, respondents were allowed to air out their views, suggestions and highlight the questions which needed to be rephrased and amendments were made where necessary.

\section{Data Collection Procedure}

Literature reviews from related studies, scholarly journals and questionnaires were sources of data for the study. A well designed questionnaire facilitated the collection of primary data. Trusted employees of the ministry under study assisted in the data collection process. In order to get permission from the Ministry of Education to collect data, written permission was obtained from the university. Questionnaires with a designed Likert scale were issued to a sample of selected employees of the Ministry of Land, Environment \& Natural resources and Mining directorates and recollected after two weeks. In order to give respondents confidence in open-ended questions, the data collection instrument was anonymous. Questionnaires that had been duly completed were collected for analysis.

\section{Data Analysis, Findings and Conclusion}

Kothari, 2004; Wainaina, (2015), clarifies that manipulation of collected data from the study area with the motive of obtaining answers to research questions is what data analysis refers to. The Statistical Package for Social Sciences (SPSS version 20.0) aided in analysing the collected data. $\quad \mathbf{Y}=\boldsymbol{\beta}_{\mathbf{0}}+\boldsymbol{\beta}_{\mathbf{1}} \mathbf{X}_{\mathbf{1}}+\boldsymbol{\varepsilon}$

Where: $Y=$ Employee Productivity; $\beta_{0}=$ Constant; $B_{1}=$ Regression coefficient component; $\mathrm{X}_{1}=$ Performance supervision; $\varepsilon=$ Error term

Table 1: Response Rate

\begin{tabular}{llll}
\hline & $\begin{array}{l}\text { Issued } \\
\text { questionnaires }\end{array}$ & $\begin{array}{l}\text { Filled and returned } \\
\text { questionnaires }\end{array}$ & Percentage \\
\hline Respondents & 66 & 61 & $92.4 \%$ \\
\hline \multicolumn{4}{c}{ Source: Author (2021) }
\end{tabular}

66 employees of Taita Taveta County, Ministry of Lands, Environment and Natural resources, were targeted as a sample for the study and were issued with the questionnaires, but only 61 questionnaires were filled in and returned, translating to a response rate of $92.4 \%$, which was sufficient for the research analysis. A response rate of above $70 \%$ is considered to be excellent, (Mugenda \& Mugenda, 2002 ;Otera, (2018). 
Table 2: Respondents' profile (Extract)

\begin{tabular}{|c|c|c|c|c|}
\hline S/No. & Characteristic & Aspect & Frequency & Percentage \\
\hline \multirow[t]{2}{*}{1.} & \multirow{2}{*}{ Gender } & Male & 30 & 49.2 \\
\hline & & female & 31 & 50.8 \\
\hline \multirow[t]{4}{*}{2.} & \multirow[t]{4}{*}{ Age category } & $20-30$ & 28 & 45.9 \\
\hline & & $31-40$ & 26 & 42.6 \\
\hline & & $41-50$ & 6 & 9.8 \\
\hline & & Above 51 & 1 & 1.6 \\
\hline \multirow[t]{7}{*}{3.} & \multirow[t]{7}{*}{ Education } & Others & 1 & 1.6 \\
\hline & & Masters & 6 & 9.8 \\
\hline & & Bachelors & 10 & 16.4 \\
\hline & & Diploma & 20 & 32.8 \\
\hline & & Certificate & 7 & 11.5 \\
\hline & & KCSE & 15 & 24.6 \\
\hline & & KCPE & 2 & 3.3 \\
\hline \multirow[t]{3}{*}{4.} & \multirow[t]{3}{*}{ Duration in service } & above 6 years & 17 & 27.9 \\
\hline & & $4-6$ years & 24 & 39.3 \\
\hline & & $1-3$ years & 20 & 32.8 \\
\hline \multirow[t]{3}{*}{5.} & \multirow[t]{3}{*}{ Staff cadre } & Junior staff & 30 & 49.2 \\
\hline & & Senior staff & 25 & 41.0 \\
\hline & & Top level & 6 & 9.8 \\
\hline
\end{tabular}

Table 2: Respondents views on whether Performance Supervision influence their daily activities

\begin{tabular}{llll}
\hline & Frequency & Valid Percent & Cumulative Percentage \\
\hline Yes & 56 & 91.8 & 91.8 \\
No & 5 & 8.2 & 100.0 \\
\hline Total & 61 & 100.0 & \\
\hline
\end{tabular}

Source: Researcher (2021)

According to the analysis, $91.8 \%$ of respondents agreed that the ministry supervisors influenced their performance, whereas $8.2 \%$ disagreed.

Table 3: Mean Interpretation Table

\begin{tabular}{cll}
\hline Weight average & Result & Result interpretation \\
\hline $1-1.79$ & Strongly agree & Very influential \\
$1.80-2.59$ & Agree & Influential \\
$2.60-3.39$ & Neutral & Neutral /Do not know \\
$3.40-4.19$ & Disagree & Uninfluential \\
$4.20-5$ & Strongly Disagree & Very uninfluential \\
\hline & Source: Alonazi, Beloff \&White (2019)
\end{tabular}

Responses to the statements below were done by ticking the options that best fitted respondents' opinions in relation to their experiences of practices in the organization. Where: Strongly Agree (1), Agree (2), Disagree (3), Strongly Disagree (4). 
Table 4: (Extract) Descriptive Statistics for Performance Supervision

\begin{tabular}{|c|c|c|c|c|c|}
\hline & $\mathrm{N}$ & Min & Max & Mean & Std. Dev \\
\hline The Ministry has rules and regulations & 61 & 1 & 4 & 1.95 & .384 \\
\hline My performance is monitored from time to time & 61 & 1 & 4 & 1.93 & .403 \\
\hline $\begin{array}{l}\text { There is relationship between my qualification and my } \\
\text { job }\end{array}$ & $\mathrm{y}_{61}$ & 1 & 4 & 2.77 & .990 \\
\hline $\begin{array}{l}\text { Ministry's policies and procedures are clear and up to } \\
\text { date }\end{array}$ & ${ }^{0} 61$ & 1 & 4 & 2.77 & 1.007 \\
\hline My duties and responsibilities are clear & 61 & 1 & 4 & 2.15 & .573 \\
\hline I work in a well-managed sector & 61 & 1 & 4 & 2.15 & .792 \\
\hline Aggregate mean & & & & 2.287 & \\
\hline Aggregate std.dev & & & & & 0.6915 \\
\hline
\end{tabular}

According to the table above, respondents (mean 1.80-2.59) agreed with the statements: The ministry has rules and regulations, my performance is monitored on a regular basis, my duties and responsibilities are clear, and I work in a well-managed sector. With statements, respondents chose to be neutral (mean 2.60-3.39): There is a relationship between my qualification and my job, and the ministry's policies and procedures are clear and up to date.

\section{Correlation Analysis}

Table 5: Relationship between Performance Supervision and Employee Productivity

\begin{tabular}{llll}
\hline & & $\begin{array}{l}\text { Performance } \\
\text { Supervision }\end{array}$ & Employee Productivity \\
\hline Performance & Pearson Correlation & 1 & $.535^{* *}$ \\
Supervision & Sig. (2-tailed) & 61 & .000 \\
& $\mathrm{~N}$ & 61 \\
\hline & $* *$ Correlation is significant at the 0.01 level (2-tailed). \\
\multicolumn{3}{c}{ Source: Author (2021) }
\end{tabular}

The table reveals the link between performance supervision and employee productivity, which is a moderate positive effect $(\mathrm{r}=0.535)$. This clearly indicates that supervision has an influence on the level of productivity among employees. Occasionally, the gentleness of the supervisory role is misinterpreted without regard for the enormous consequences it can have on workforce output. It plans to capitalize on its achievements in the future. It is unsurprising that supervisors in workplaces have proven to be the primary impediment to achieving credible success in organizations. (Omisore, 2014) 


\section{Regression Models}

Table 6: Performance Supervision ANOVA ${ }^{\mathrm{a}}$

\begin{tabular}{lllllll}
\hline Model & Sum of Squares & df & Mean Square & F & Sig. \\
\hline \multirow{4}{*}{1} & Regression & 4.402 & 1 & 4.402 & $23.640 .000^{\mathrm{b}}$ \\
& Residual & 10.987 & 59 & .186 & & \\
\hline & Total & 15.389 & 60 & & & \\
\hline
\end{tabular}

a. Dependent Variable: Employee Productivity

b. Predictors: (Constant), Performance Supervision

Source: Author (2021)

The ANOVA test in the table above shows the significance of Fstatistics. 0.000 is less than 0.05 , meaning that there is a relationship between performance supervision and employee productivity.

Table 7: Performance Supervision and Employee Productivity regression model

\begin{tabular}{|c|c|c|c|c|c|c|c|}
\hline Model & $\mathrm{R}$ & R Square & $\begin{array}{l}\text { Adjusted R Std. Error of } \\
\text { Square the Estimate }\end{array}$ & $\begin{array}{l}\text { Change Statistics } \\
\text { R Square F Chang } \\
\text { Change }\end{array}$ & & df2 & $\begin{array}{l}\text { Sig. F } \\
\text { Change }\end{array}$ \\
\hline 1 & $.535 a$ & .286 & .4315294 & 23.640 & 1 & 59 & .000 \\
\hline
\end{tabular}

From the findings, the value of the coefficient of $\mathrm{R}$ is 0.535 , representing 53.5.0\%. This shows that there is a strong coefficient between the study variables. The value of $\mathrm{R}^{2}$ is 0.286 , which represents $28.6 \%$ and indicates that there are other factors other than performance supervision that affect employee productivity.

Table 8: Performance Supervision Coefficients

\begin{tabular}{|c|c|c|c|c|c|c|}
\hline \multirow[t]{2}{*}{$\overline{\text { Model }}$} & & \multicolumn{2}{|c|}{$\begin{array}{l}\text { Unstandardized } \\
\text { Coefficients }\end{array}$} & \multirow{2}{*}{$\begin{array}{l}\text { Standardized } \\
\text { Coefficients } \\
\text { Beta }\end{array}$} & \multirow[t]{2}{*}{$\mathrm{t}$} & \multirow[t]{2}{*}{ Sig. } \\
\hline & & B & Std. Error & & & \\
\hline & (Constant) & .719 & .366 & & 1.961 & .055 \\
\hline 1 & $\begin{array}{l}\text { Performance } \\
\text { Supervision }\end{array}$ & .834 & .172 & .535 & 4.862 & .000 \\
\hline
\end{tabular}

a. Dependent Variable: Employee Productivity

source :Researcher(2021)

\section{$Y=0.719+0.834 X_{1}$}

The results on beta coefficients of the resulting model on performance supervision show that the constant $\alpha=0.719$ is significantly different from 0 , since the $\mathrm{p}$-value $=0.000$ is less than 0.05 . The coefficient $\beta=0.834$ is also significantly different from 0 with a p-value $=0.000$, which is less than 0.05 . This implies that there is a positive relationship between performance supervision and employee productivity. 
At the 95\% level of significance, performance supervision is significant at 0.000 , and employee productivity has a beta coefficient of 0.834 .This explains that performance supervision has an effect on employee productivity.

\section{Findings}

Based on the results, the ministry has supervisors in its sub-sections, with 91.8 percent of employees agreeing to the fact that supervisors influence their productivity levels. The employees agreed that monitoring of employee performance is carried out within the ministry. Rules and regulations govern the conduct of employees. Duties and responsibilities were also clear and employees believed they were working in a well-managed sector. However, employees choose to be neutral concerning the relationship between their qualifications and the assigned job as well as the ministry's policies and procedures being clear and up to date.

\section{Conclusion}

Coordination and directing of activities to realize the established goals depends on the success of the supervisors. Having great supervisors ensures that communication channels are kept open in both directions, resulting in a safe, industrious, and hardworking environment. Performance supervision is critical in matters of employee productivity and supervisors need to be empowered to control and direct their subordinates towards the ministry's goals. The fact that employees chose to be neutral concerning the matching of their qualifications and the assigned jobs, proved that most of the employees were not properly placed. The ministry has outdated policies and procedures that need to be revised in order to deal with the problems that have arisen, particularly with land issues.

The ministry needs to strive towards achieving effective supervision by having proper policies and procedures which will guide supervisors in their daily activities. This offers an innocuous environment for employees to cultivate their abilities and an understanding of their job, as well as to reflect on their own practice. Changing aspects revolving around the supervisory role make its delivery heavily rely on the organizational framework. Providing them with relevant training and support and allowing them to properly place their subordinates will reduce the challenges they encounter while executing their mandate.

\section{The study's implications and limitations}

For the Ministry to realize high output, the outcome points in the direction of good supervision, which is believed to contribute to increased job satisfaction, increased job and organizational commitment among staff, and reduced employee turnover. 
When used on a large scale, case studies have proven to be very expensive and time-consuming,(McLeod,2019), hence the small sample size.

\section{References:}

1. Adams J. S. (1963). Towards an understanding of inequity. The Journ.al of Abnormal and Social Psychology, 67(5), 422.

2. Alonazi M., Beloff N., \&White M. (2019): Exploring Determinants of M-Government Services: A Study from the Citizens' Perspective in Saudi Arabia Proceedings of the Federated Conference on Computer Science and Information Systems pp. 627-631 DOI: 10.15439/2019F75 ISSN 2300-5963 ACSIS, Vol. 18. IEEE Catalog Number: CFP1985N-ART c 2019, PTI

3. Ataullah A., Le H. \& Sahota A.S. (2014). Employee Productivity, Employment Growth, and the Cross-Border Acquisitions by Emerging Market Firms, Human Resource Management, 53(6), 987-1004

4. Babbie, R. (2013). The practice of social research. 13th ed. Belmont, CA: Wadsworth Cengage Learning

5. Bell R. \& Martin J. (2012). The Relevance of Scientific Management and Equity Theory in Everyday Managerial Communication Situations; Journal of Management Policy and Practice, Vol. 13(3) 2012. Available at SSRN: https://ssrn.com/abstract $=2372166$

6. Benowitz L. (2017). Justice at Work: Towards an Adaptive Workplace (Doctoral dissertation).

7. C.M. Kelly, Y. Rofcanin, M.L. Heras, \& C. Ogbonnaya , E. Marescaux, M. José Bosch,(2020): "Seeking an "i-deal" balance: Schedule flexibility i-deals as mediating mechanisms between supervisor emotional support and employee work and home performance," Journal of Vocational Behavior, vol. 118, pp. 103369, 2020

8. Hamid, H., Haming, M., Semmaila, B \& Bijang, J. (2020). A mediation effect of new public management on the relationship between intelligence, leadership, HR quality and performance of local government employees in Indonesia.Management Science Letters, 10(7), 1401-1408.

9. Hannang A, Salju \& Qamaruddin M.Y,(2020): The Effect of Supervision Levels on Employees' Performance Levels, Advances in Social Science, Education and Humanities Research, volume 477 Proceedings of the International Conference on Community Development (ICCD 2020)

10. Ime U.,Victor A.,Osemudiamen D.and Efiok N.(2015):Effective Performance Management Systems and Employee Productivity: Evidence from Multichoice Company, Nigeria. International Journal 
of Management Sciences and Business Research, May-2015 ISSN (2226-8235) Vol -4, Issue 5.

11. Inuwa M. (2017). Relationship between Job Equity and Performance of Employee: A Literature Review; International Journal of Business and Management Future Vol. 1, No. 1; 2017.

12. Jalal Hanaysha. (2016). Improving employee productivity through work engagement: Empirical evidence from higher education sector. International Journal of Industrial Engineering Computation

13. Kihama J.W. \&Wainaina L. (2019). Performance appraisal feedback and employee productivity in water and sewerage companies in Kiambu County, Kenya. International Academic Journal of Human Resource and Business Administration, 3(5), 376-393

14. Kopaneva I\&. Sias P(2015); Employee and Organizational Constructions of Mission and Vision ,Published April 14, 2015 Research Article; https://doi.org/10.1177/0893318915581648

15. Koske D. K \& Atambo W. (2018): Effects of Supervision On Employee Performance: A Case of Kenya Tea Packers Limited (KETEPA) Company, Kenya International Journal of Core Engineering \& Management Volume-5, Issue-7, October-2018, ISSN No: $2348-9510$

16. Kothari, C. R. (2004). Research Methodology: Methods and Techniques.2nded. New Delhi. New Age International (P) Ltd.

17. Latham G. P. \&Locke E. A. (2017); Motivate Employee Performance Through Goal Setting pp 162.

18. Lee W.C \& Kusumah A. ,(2020): Influence of Supervision on Employee Performance with Work Motivation as an Intervening Variable. Review of Integrative Business and Economics Research, Vol. 9, Supplementary Issue 2. Copyright $\square 2020$ GMP Press and Printing

19. Leung L. (2015). Validity, reliability and generalizability in qualitative research. Journal of Family Medicine \& Primary Care, 4(3), 324-327.

20. Lubis\& Ibrahim. 2015. Project Control and Supervision in Management. Jakarta: Ghalia Indonesia

21. Min J, Iqbal S, Khan MAS, Akhtar S, Anwar F, Qalati SA (2020): Impact of supervisory behaviour on sustainable employee performance: Mediation of conflict management strategies using PLSSEM. PLoS ONE 15(9): e0236650. https://doi.org/10.1371/journal.pone.0236650

22. Naissuma D. K (2008) Survey and sampling Theory \&methods. Njooro, Kenya. Egerton University Press. 
23. NST, A. E., \& Lesmana, M. T. (2018, May 26). Influence of work discipline and supervision to increasing employee productivity in pt. Citra Robin Sarana Medan. retrieved from osf.io/pvj7e

24. Okeke M. N., Onyekwelu N. P., Akpua J., \&Dunkwu C. (2019). Performance management and employee productivity in selected large organizations in south-east, Nigeria. IJRDO - journal of business management ISSN: 2455-6661.

25. Omisore, B.O(2014); Supervision - Essential to Productivity, Centre for Management Development, Shangisha, Lagos, Nigeria. G.J.C.M.P., Vol.3(2):104-108; ISSN: $2319-7285$

26. Otera C. (2018); Job satisfaction and employee performance in the Telecommunication Sector in Kenya: a case of Telkom Kenya ltd

27. Paula L, Sanna P, Juhani U, \&Helina M(2014): Defining and measuring productivity in the public sector: Managerial perceptions.https://www.researchgate.net/publication/235317696

28. Riaz, A., \& Mahmood, H. Z. (2017). Cross-Level Relationship of Implemented High-Performance Work System and Employee Service Outcomes: The Mediating Role of Affective Commitment. Pakistan Journal of Commerce and Social Sciences, 11(1), 252-274

29. Rulandari N. (2017); The Effect of Supervision and Professionalism on Staff Performance at the Office of Social Affairs in East Jakarta Administrative City. International Journal of Humanities and Social Science Vol. 7, No. 2; February 2017.

30. S. Mcleod (2019): Research Methods. https://www.simplypsychology.org/case-study.html

31. S. Syamsuddin, A.R. Kadir, \& S. Alam, "Improving performance of civil servants: The effect of leadership, work motivation and competence," Hasanuddin Journal of Applied Business and Entrepreneurship, vol. 3 no. 1, 2020

32. Sinambela, Lijan P. (2016). Manajemen Sumber Daya Manusia. (Cetakan pertama). Jakarta: PT Bumi Aksara

33. Tara D. (2016). How would you apply the equity theory in a performance appraisal? Retrieved from http://smallbusiness.chron.com/would-apply-equity-theoryperformance-appraisal-42087.html on 23rd November, 2016

34. Wainaina L.W.(2015).Determinants of organizational commitment among academic staff inKenya's public and private universities. A thesis submitted to Jomo Kenyatta University of Agriculture and Technology

35. Warrens M. (2015). Some Relationships between Cronbach's Alpha and the Spearman-Brown Formula. Journal of Classification, 32(1), 127-137. 